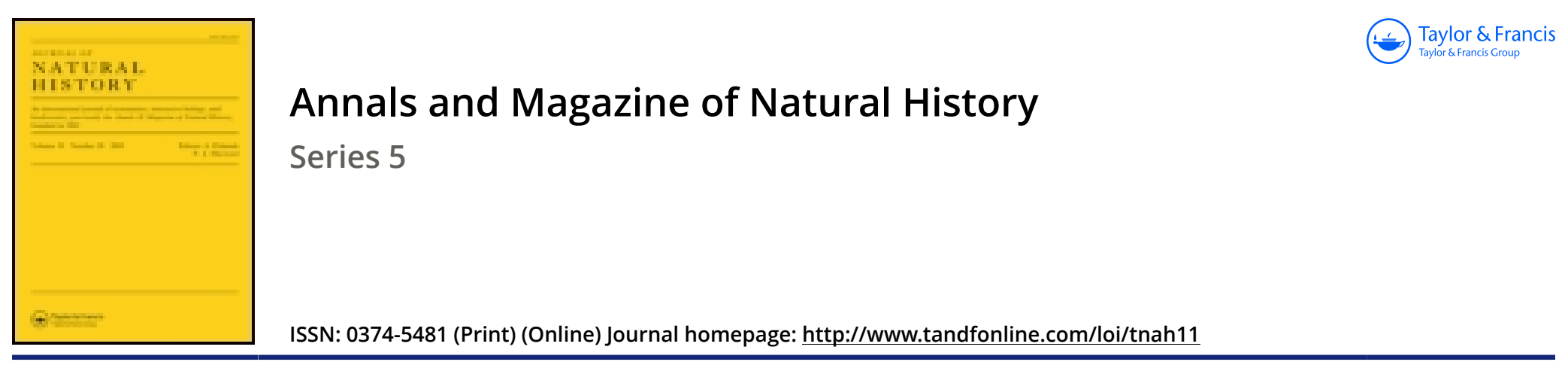

\title{
On a new form of segmental organ in the Trematodes
}

\section{M.E. Macé}

To cite this article: M.E. Macé (1881) On a new form of segmental organ in the Trematodes, Annals and Magazine of Natural History, 7:40, 354-355, DOI: 10.1080/00222938109459529

To link to this article: http://dx.doi.org/10.1080/00222938109459529

曲 Published online: 07 Oct 2009.

Submit your article to this journal $\pi$

Џ Article views: 3

Q View related articles $₫$ 
which constitute this spherule become fewer and fewer; they seem to separate from each other; and finally they disappear; the nucleus is then represented only by its envelope, which looks like an empty shell. While the nucleus is undergoing these transformations the contractile substance gradually disappears, melting away, so to speak, and this in so regular a manner that the general form of the bundle is not altered. The product of this sort of dissolution seems to be a colourless very finely granular substance, enveloping the portion of the contractile mass that has not yet disappeared. In this granular mass we find the muscular nuclei in their place and in all the degrees of degeneration that I have just indicated.

Thus the museles of the larva are destroyed at the moment when the latter passes to the pupa state, and this in two quite different modes. In the first case the muscular nuclei, becoming actire, proliferate and give origin to a whole swarm of embryonic cells; and these grow and multiply at the expense of the contractile mass, which seems to disappear before their invasion. In the second case the muscular nuclei seem to degenerate and die, while the contractile substance gradually disappears as by a regular solution.Comptes Rendus, February 21, 1881, p. 416.

\section{On a new Form of Segmental Organ in the Trematodes.}

By M. E. Mact.

The authors who have observed the ciliated organs in connexion with the vasculo-excretory apparatus of the Trematodes (Thiry, Bütschli, $\delta$. Fraipont) have described them in the species that they have studied as little ciliated funnels, often unicellular, each bearing upon a differentiated plate a vibratile flagellum. In studying a small Distomum from the intestine of Vespertilio murinus we have ascertained the existence of a very distinct conformation.

The ciliated organ is single. It is a pretty large cup situated in the median line towards the posterior third of the body, immediately beneath the transverse vitelloduct. Its diameter is nearly half that of the ventral disk, which is situated a little above it. Its orifice, turned towards the ventral surface of the body, is clothed with a row of long vibratile cilia, which, when they are in movement, give it the aspect of one of the ciliated wheels of certain Rotifera. From this ciliated funnel start four vessels. The two superior are directed upwards, and soon elude observation. The two inferior have a transverse direction; after a short course they open each into the corresponding branch of the great terminal cavity of this apparatus.

This Distomum has great analogy with $D$. ascidia of Van Beneden. It differs from it, however, in the place occupied by the vitellogenes. Instead of being in the anterior part of the body, in front of the second disk, they occupy its posterior part. They are two ramified glands in the form of an $\mathbf{H}$, situated below the ovary, against the upper extremity of the two large branches of the excretory vesicle; the transverse vitelloduct passes immediately above the ciliated organ in question, and presents a pyriform dilatation in its median part. The intestine is formed by two wide crea, which 
scarcely reach the level of the second disk.-Comptes Rendus, February 21,1881 , p. 420 .

On the Circulation and Respiration of the Ophiuridæ.

By M. N. Ápostoumbis.

Having had at my disposal numerous living Ophiurans in the laboratories of Roscoff, the Sorbonne, and Port Vendres, I have been able to apply to these animals peculiar processes of fine injection; and these processes have furnished me with novel results, which I have the honour to communicate to the Academy. My investigations have been made upon the following species:-Ophiura texturata, Lam.; Ophiura albida, Forbes ; Ophiocoma granulata, filiformis, and neglecta, Forbes ; and Ophiocoma rosula, Johnst.

1. After a successful injection of the aquiferous system, on dissecting the interbrachial space of the madreporic plate, we come upon a dilated whitish canal, rendered rigid by calcareous plates; and on tearing this canal we see, towards the middle, a brownish inflated mass, the supposed heart of authors, on the side of which there is a fillet containing the injected material. This fillet is the sand-canal. This experiment, frequently repeated upon different species, shows that the sand-canal becomes injected at the same time as the aquiferous system, and that the supposed heart is independent of that system ; further, the particles of injected material found outside the madreporic plate prove that the sand-canal, extending from the aquiferous ring to that plate, establishes a direct communication between the aquiferous system and the exterior.

2 . "The heart is the true centre of the circulation .... it is a plexus of anastomosing vessels which unites the two rings, oral and aboral." It is thus that M. H. Ludwig defines the structure and function of the heart. With regard to the two rings, at the discovery of which he arrived by coloration with hæmatoxyline, he admits that he knows " neither their contents nor their stmucture."

The organ called the heart presents very various structures and relations. By a careful dissection it is easy to see that it has an elongated form, and is produced into a rectilinear canal going to the madreporic plate; an injection, forced into the brown mass which represents it, immediately fills this prolongation and appears on the outer surface of the madreporic plate. Its structure, when studied in a heart taken from a living animal, shows that it is a gland with a proper excretory canal opening outward, and not an organ of circulation. On each side of this hitherto misunderstood gland we see two small fibrous bands, directed laterally towards the base of the arms; they become vividly coloured by hæmatoxyline, like the analogous bands which sustain the Polian vesicles; but the liquid injected into the heart never went in their direction.

3. An injection forced between the integument and the digestive tube (that is to say, into the general cavity) never shows itself externally, and never penetrates into the aquiferous system. The general cavity is therefore entirely closed; it is formed of a widened portion surrounding the digestive tube (peristomachal space), which 